\title{
MDCTに打けるガントリ傾斜補正の評価 一MPR西像に及ぼす影響一
}

\author{
名定敏也 - 平山伸一 - 田ノ岡征雄 - 藤田知子 - 酒井敏行
}

2002年 7角29日

論文受理

2002年11月7日

兵庫医科大学病院中央放射線部

Code No. 251

\section{緒 言}

近年，X線computed tomography (CT) 検查では, multi detector-raw CT (以下MDCT)の登場によりZ軸 分解能が飛躍的に向上した. その結果, 臨床診断にお いて multi planar reconstruction (以下MPR) 画像が利用 されることが多くなってきた. しかし，義歯や体内金 属などによるアーチファクトが診断の妨げになること も少なくない：このアーチファクトを軽減させるため にガントリ傾斜させて撮影する必要がある。この際, single detector-row CT (以下SDCT)によるspiral scan
においては，ガントリ傾斜することにより再構成され る平面 (X-Y平面) と寝台移動方向との垂直関係が崩 れ，これにより $\mathrm{Y}$ 軸方向の空間分解能が劣化すること が報告されている1，2)，MDCTによるspiral scanでは， これに加えガントリ傾斜することにより検出器各列の スキャン中心がY軸方向にシフトする。これを画像再 構成時に補正しなければならない。また, 寝台移動距 離の補正も必要となる ${ }^{3)}$. SIEMENS社SOMATOM Plus4 Volume Zoom (以下VZ)では, softwareでこれら の補正が可能となった。 そこで今回われわれは，ガン

\section{Evaluation of Gantry Tilt Correction in Multi Detector-row CT: Effect on Multi-Planar Reconstruction Images}

\section{TOSHIYA NASADA, SHINICHI HIRAYAMA, MASAO TANOOKA, TOMOKO FUJITA, and TOSHIYUKI SAKAI}

Department of Radiology. Hospital of Hyogo College of Medicine

Received July 29, 2002; Revision accepted Nov. 7, 2002; Code No. 251

\section{Summary}

In multi-slice CT, the scanning center of each line multiple-row detector array is shifted in the $\mathrm{Y}$-axis direction by the tilting of the gantry. Correction of this effect is necessary when.CT images are reconstructed. Correction of table feed is necessary as well. These corrections are possible with the Somatom Plus 4 Volume Zoom. The use of multi-planar reconstruction(MPR) images has been increasing rapidly in the area of clinical diagnosis. Therefore, we examined the influence of MPR images according to gantry tilt. For each gantry tilt, the spatial resolution of MPR images was almost the same even though scanning pitch was changed. When the gantry was tilted, the full width at half maximum (FWHM) of the section sensitivity profile (SSP) was about $10 \%$ to $20 \%$ wider than that when the gantry was not tilted. The spatial resolution of MPR images is more affected by whether or not the gantry is tilted than by the angle of tilt. Gantry tilt correction is useful to obtain images without artifact for metal and artificial teeth; however, deterioration in spiral resolution cannot be avoided.

Key words: Computed tomography (X-CT), Multi detector-row CT, Gantry tilt, Multi-planar reconstruction (MPR) 
トリチルトかMPR画像に及はす影箁を, section sensitivity profiles (以下SSP) より検討し，ガントリ傾斜補 正の評価とした。

\section{1. ガントリ傾斜峬正}

4 列のMDCTにおけるガントリ傾斜の影響(スパイ ラルピッチ 4)をFig. 1に示す.ガントリ傾斜なしでの スキャンではFig. 1aのようにY軸，Z軸方向ともにず れは生じないが，ガントリ傾斜させることにより，

Fig. 1bのように四つの検出器列のスキャン中心がずれ る.また，Z軸方向にも重なりが生じる．これを次式 により補正している(Fig. 2).

Y軸の再構成位置のずれ

$A=B \times \sin \theta$

$A ： Y$ 軸の再構成位置のずれ

$B$ : slice中心からdetectorまでの距離

$\theta$ ：ガントリ傾斜角度

Z軸方向のFeedのずれ

$C=D / \cos \theta$

$C:$ Z軸方向のFeedのずれ

$D ：$ ガントリ傾斜なしのFeed幅

$\theta$ ：ガントリ傾斜角度

これらの補正には誤差が含まれる可能性があり，Z 軸方向の補正を例にして説明する，補正が正確に行わ れるとFig. 3aのようになるが, Fig. 3b，cのように若 干のオーバラップやギャップといった補正誤差が生じ る場合がある。例えば，スライスコリメーション $4 \times 1.0 \mathrm{~mm}$ ，スパイラルピッチ 4 について考える. ガン トリ傾斜なしでは, テーブル移動距離は $4.0 \mathrm{~mm} / \mathrm{rot}$ と なる。これをガントリ傾斜 $20^{\circ}$ とするとテーブル移動 距離は前述の補正式から

$4.0 / \cos \left(20^{\circ}\right)=4.27$

となる。しかし実際はテーブルフィードの制御は $0.1 \mathrm{~mm}$ 単位でしかできないため, 約-0.03mmの補正誤 差(ギャップ)が生じる。このような補正鿁差は，Y軸 方向の補正においても同様に起こる、Y軸方向の補正 では，4列の検出器それぞれに補正をかけるため，検 出器ごとに補正誤差の大きさがそれぞれ違ってくる可 能性がある。 また, 画像再構成時のデータの切り出し 位置によっても䛊差の生じ斿に変化が起きる。これら の誤差は実データおよび対向データそれぞれに影響す る.これらのことが画像再構成時の非線形多点補間に 複合的要因として加わることになり，再構成された画 像は，それぞれ違った誤差を持つことになる。

\section{2. 方 法}

\section{2-1 使用機器}

X線CT装置 SOMATOM Plus4 Volume Zoom

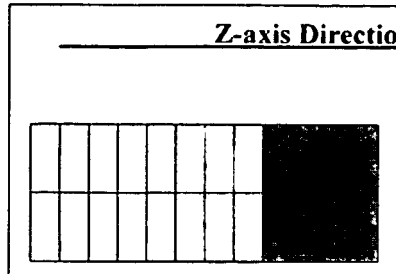

(a)Without Gantry Tilt

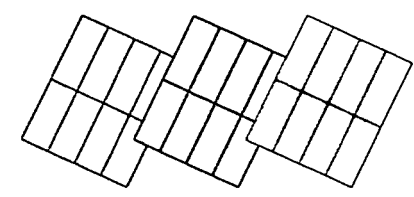

(b)With Gantry Tilt
Fig. 1 Influence of gantry tilt in four MDCT detectors (spiral pitch: 4).

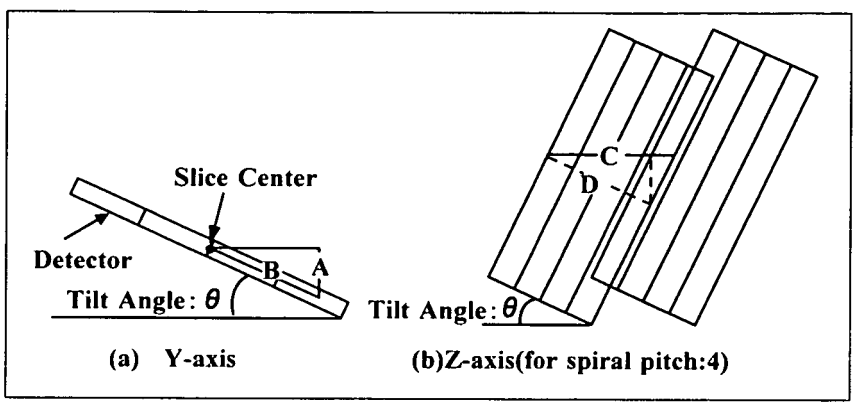

Fig. 2 Gantry tilt correction.

(SIEMENS旭メディテック株式会社，4列検出器 MDCT)

微小球体：0.2 mm径タングステン球

\section{2-2ＳSPの評価法}

本法はガントリを傾斜させるため, ファントムのア ライメントの影響を受けにくい微小球体法にて行っ たＳSPの評価としては，Y軸，Z軸方向にガンドリ傾 斜補正の影響が現れると考えられるためX軸，Y軸， Z軸それぞれの方向について行う必要がある。まず, 冠状断像 $\left(X-Z\right.$ 平面) 加ら矢状断像 $(Y-Z$ 平面 $)$ ح $10^{\circ}$ 間隔 のMPR画像を実機にて作成し(Fig. 4)，PC (personal computer)それぞれの画像のhorizontal方向のプロファ イルカーブから半值幅 (FWHM : full width at half maximum) および1/10幅 (FWTM : full width at tenth maximum)を求めた。これは，X-Y平面におけるSSP の変化を測定していることになる.X-Z平面では横断 像から (horizontal方向のプロファイルカーブ), Y-Z平 面では横断像から冠状断像 (vertical方向のプロファイ ルカーブ)へのMPR画像を用いた4、5).この際の横断 像とはガントリに対して平行な面を指し, 冠状断像, 矢状断像は横断像に対して垂直な面在指す。

撮影条件は，管電圧 $120 \mathrm{kV}$ ，管電流70Eff.mAs，ス キャン時間 $0.5 \mathrm{sec} / \mathrm{rot}$ とし，X-Y面内でエリアシング エラーを生じないfield of view(以下FOV：50mm $512 \times 512$ matrix) とした。測定スライスコリメーション は $4 \times 1.0 \mathrm{~mm}, 4 \times 2.5 \mathrm{~mm}$ とし, 再構成スライス厚は 


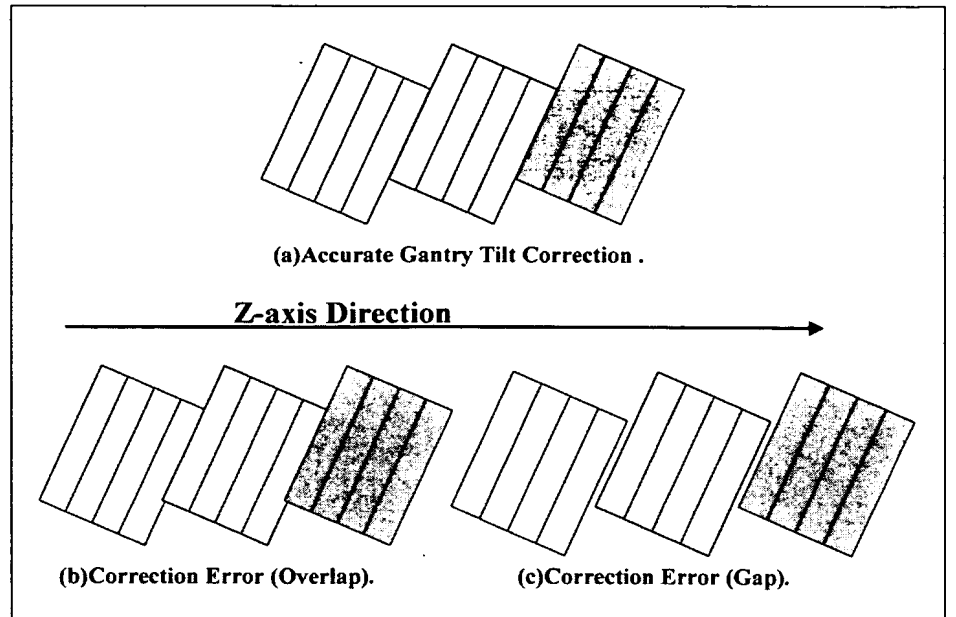

Fig. 3 Gantry tilt correction in four MDCT detectors (spiral pitch: 4).

$1.0 \mathrm{~mm}, 3.0 \mathrm{~mm}$ ，再構成間隔はともに $0.1 \mathrm{~mm}$ とた。 なおEff.mAsは次のように定義されている6).

Eff.mAs $=\mathrm{mA} \times$ rot.time $/($ pitch $/ 4)$

\section{2-3ガントリ傾斜補正の評価}

\section{2-3-1スパイラルピッチによる影響}

VZでは, adaptive axial interpolation(以下AAI) という 非線形多点補間を用いることで，スパイラルピッチを 変化させても実効スライス厚が変化しないとされてい る6). ガントリ傾斜させた場合にもスパイラルピッチに 関係なくスライス厚が一定になるか調べるため, 測定 スライスコリメーション $4 \times 1.0 \mathrm{~mm}, 4 \times 2.5 \mathrm{~mm}$ とし，ス パイラルピッチを $3,5,7$ と変化させた場合のsection sensitivity profiles on Z-axis（以下SSPz)を求めた。また, スパイラルピッチの変化による影響として，実・対向 データのサンプリング密度が変化することが挙げられ る7). スパイラルピッチが大きくなるとサンプリング密 度が疎になり，スパイラルピッチが小さくなるとサン プリング密度が密になるサンプリング密度が踈にな ると各データの画像再構成時の重み付けが重くなる. これにより補正誤差の関与が大きくなると考えられ る，逆に，サンプリング密度が密になると補正誤差の 要因が増えることになる。以上の事から，ガントリ傾 斜をつけた場合，スパイラルピッチの違いにより空間 分解能が変化する可能性がある。この事から, MPR画 像への影響についてもSSPを用いて評価した.

\section{2-3-2 ガントリ傾斜による影響}

ガントリ傾斜を $0,15,25^{\circ}$ と変化させた場合の SSPの半値幅と $1 / 10$ 幅を求めた。 スパイラルピッチは 3 とした.

\section{2-3-3 撮像領域の辺縁部での評価}

診断に利用されるMPR画像はスキャンの中心部のみ

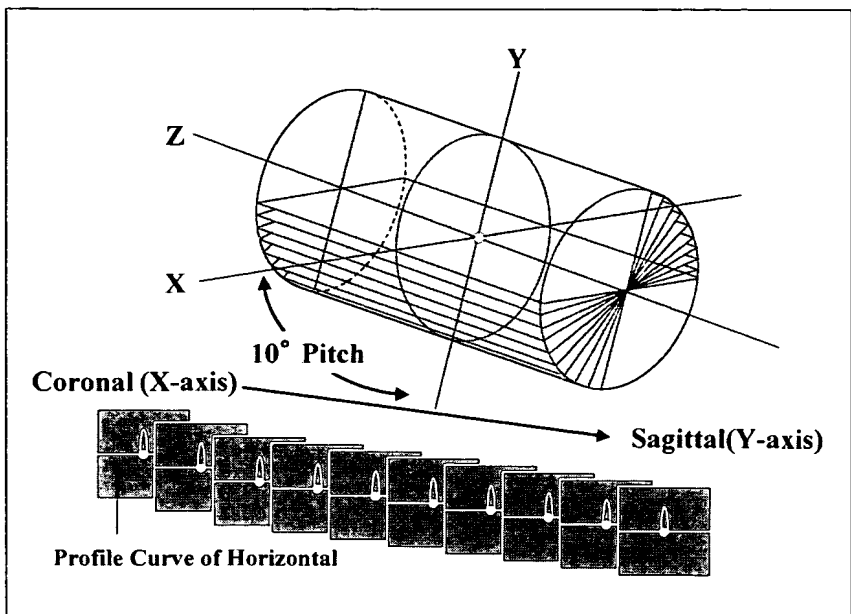

Fig. 4 MPR image used in preparation for spatial resolution measurement of the $X-Y$ plane.

ではないため，中心よりY軸方向およびX軸方向に $15 \mathrm{~cm}$ 変位(Fig. 5) させた位置においてスパイラルピッ チおよびガントリ傾斜の影響について評価した8,9).

\section{2-3-4 面内空間分解能}

MPR画像を再構成する元画像のaxial面内modulation transfer function (以下MTF) を測定した。测定法は $0.2 \mathrm{~mm}$ のワイヤファントムをスキャン中心に配置し， ワイヤをスライス面に対して垂直に保持した。エリア シングエラーの無視できるFOV $(50 \mathrm{~mm}$ $512 \times 512$ matrix) を用いてline spread function (LSF) と， そのフーリエ変換をMTFとした。

\section{3. 結 果}

\section{3-1 スパイラルピッチによる影響}

Fig. 6にガントり傾斜 $25^{\circ}$ でスパイラルピッチを変化 させたときのSSPzを示す。スパイラルピッチに関係 なく各コリメーションとも実効スライス厚は一定であ った。また，Fig.7にスキャン中心における横断像か ら冠状断像(Y-Z平面)へのMPR画像におけるSSPの半 值幅の変化を示す．各コリメーションともピッチを変 化させても，半值幅に変化はみられなかった。

\section{3-2 ガントリ傾斜による影響}

Fig. 8にガントリ傾斜を変化させた場合の横断像か ら冠状断像 (Y-Z平面)におけるSSPの半值幅の変化を 示す. スライスコリメーション $4 \times 1.0 \mathrm{~mm}$ では，ガン トリ傾斜させることにより，半值幅が最大で $26 \%$ 広 がった．ガントリ傾斜させた場合，その角度に関係な く半值幅はほほ同等となった。また，スライスコリメ ーション $4 \times 2.5 \mathrm{~mm}$ の場合も同様で，最大で $16 \%$, 半 值幅が広がった。 


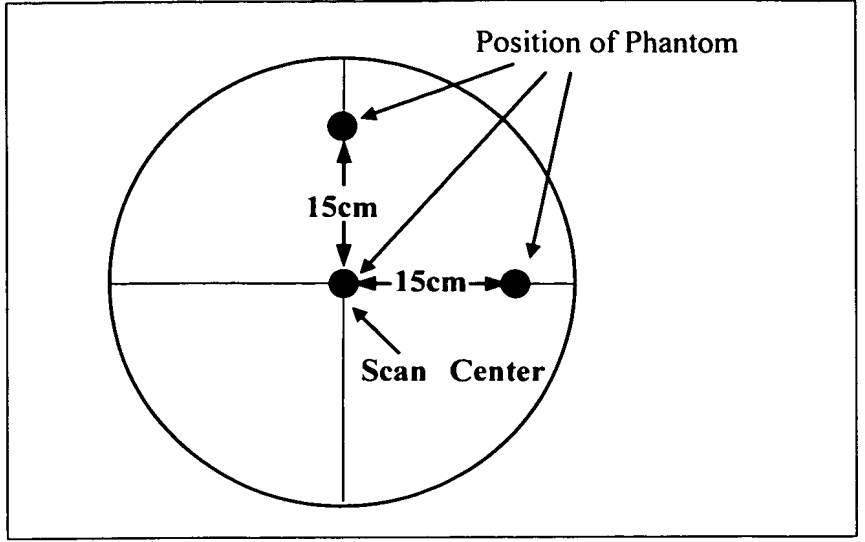

Fig. 5 Geometry.

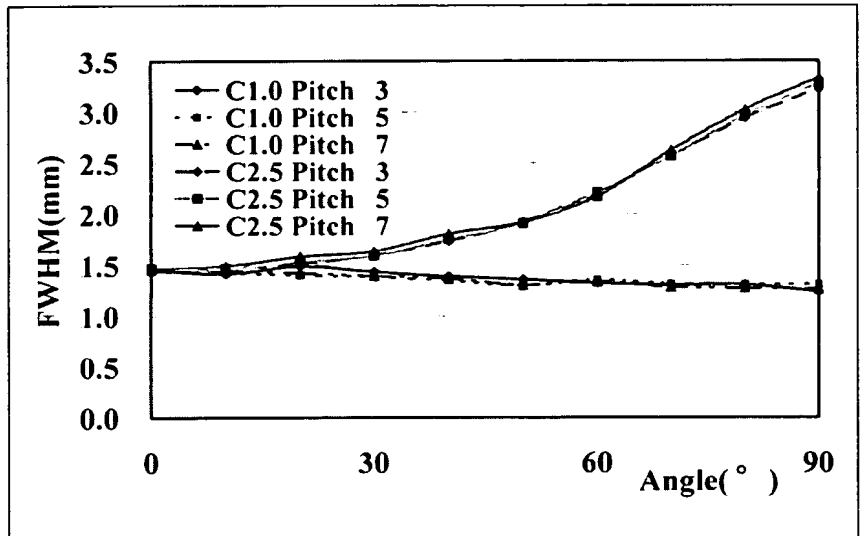

Fig. 7 Relation of FWHM to spiral pitch in the $Y-Z$ plane (scan center).

0: FWHM of SSP on the Y-axis; 90: FWHM of SSP on the Z-axis.

\section{3-3 撮像領域の辺縁部での評価}

撮像領域の辺縁部においてもスパイラルピッチによ る変化はみられなかった．Fig.9にスキャン位置がY軸 方向に $15 \mathrm{~cm}$ 変位した場合の横断像から冠状断像 (Y-Z 平面)へのMPR画像に扔ける半值幅を示す。スライス コリメーション $4 \times 1.0 \mathrm{~mm}$ では，ガントリ傾斜させる ことにより，半值幅が最大で18\%広がった．また，ス ライスコリメーション $4 \times 2.5 \mathrm{~mm}$ では, 最大で $8 \%$, 半値幅が広がった，スキャン中心と比ベガントリ傾斜 による影響は少なくなくなった。また，X軸方向への 変位についても同様であった。

Tableに矢状断像から冠状断像 (X-Y平面)における 被写体位置 ( $\mathrm{Y}$ 軸方向に $15 \mathrm{~cm}$ 变位) と半值幅, $1 / 10$ 幅の 関係を示す。この場合，被写体位置がY軸方向に変位 しているので，X軸方向に比べY軸方向の方が半值幅 の広がりが14\%大きくなった．X軸方向に変位させた 場合この逆となり，Y軸方向に比べX軸方向の方が半 值幅の広がりが $12 \%$ 大きくなった。ガントリ傾斜にお ける影響は，半值幅では，スキャン中心，1/10幅では

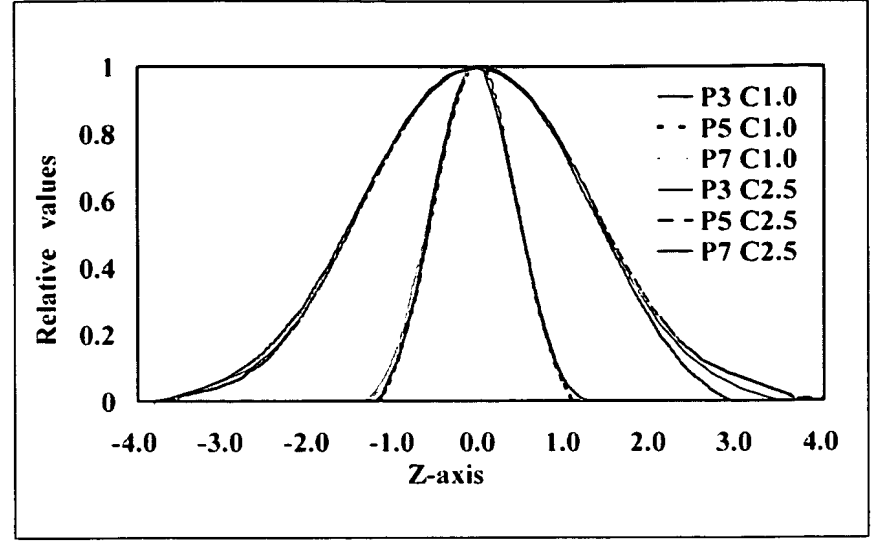

Fig. 6 Slice sensitivity profiles on the Z-axis (with gantry tilt).

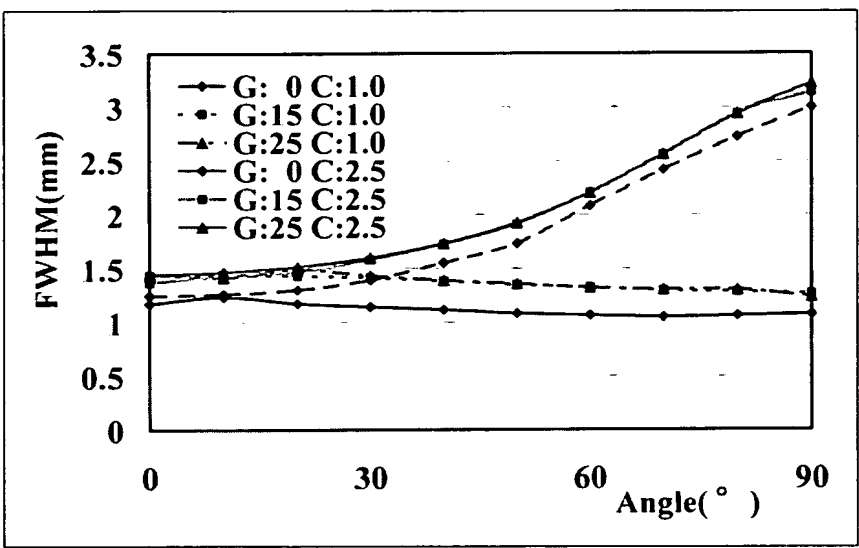

Fig. 8 Relation of FWHM to gantry tilt in the $Y-Z$ plane. 0 : FWHM of SSP on the Y-axis; 90: FWHM of SSP on the Z-axis.

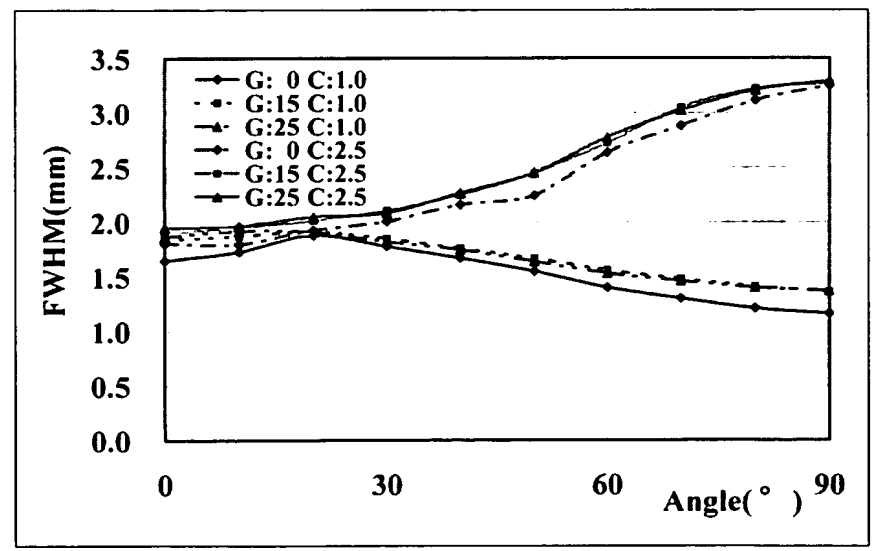

Fig. 9 Relation of FWHM to scan position in the $Y$-Z plane (shifted in the $Y$-axis at $15 \mathrm{~cm}$ ). 0 : FWHM of SSP on the Y-axis; 90: FWHM of SSP on the Z-axis.

スキャン中心から変位した場合のほうが大きくなっ た。これらは，他の方向に扮いても同様の結果となっ た。 
Table Relation of full width at half maximum and full width at tenth maximum to scan position in the $X-Y$ plane. (0: FWHM and FWTM of SSP on the X-axis, 90: FWHM and FWTM of SSP on the Y-axis)

\begin{tabular}{|c|c|c|c|c|c|c|c|c|c|c|c|c|}
\hline & \multicolumn{6}{|c|}{ FWHM } & \multicolumn{6}{|c|}{ FWTM } \\
\hline & \multicolumn{2}{|c|}{ G: 0} & \multicolumn{2}{|c|}{ G: 15} & \multicolumn{2}{|c|}{ G: 25} & \multicolumn{2}{|c|}{ G: 0} & \multicolumn{2}{|c|}{ G: 15} & \multicolumn{2}{|c|}{ G: 25} \\
\hline & Center & Shift & Center & Shift & Center & Shift & Center & Shift & Center & Shift & Center & Shift \\
\hline 0 & 1.28 & 1.61 & 1.43 & 1.70 & 1.46 & 1.71 & 2.10 & 2.58 & 2.35 & 2.99 & 2.41 & 2.84 \\
\hline 10 & 1.23 & 1.66 & 1.45 & 1.77 & 1.46 & 1.71 & 2.09 & 2.68 & 2.43 & 2.82 & 2.44 & 2.82 \\
\hline 20 & 1.25 & 1.63 & 1.45 & 1.77 & 1.46 & 1.79 & 2.02 & 2.62 & 2.45 & 2.74 & 2.45 & 2.75 \\
\hline 30 & 1.28 & 1.64 & 1.46 & 1.78 & 1.47 & 1.82 & 2.05 & 2.78 & 2.47 & 2.80 & 2.49 & 2.89 \\
\hline 40 & 1.28 & 1.63 & 1.46 & 1.75 & 1.47 & 1.80 & 2.03 & 2.84 & 2.49 & 2.67 & 2.57 & 3.25 \\
\hline 50 & 1.25 & 1.64 & 1.45 & 1.78 & 1.47 & 1.85 & 2.07 & 2.86 & 2.46 & 2.73 & 2.44 & 3.44 \\
\hline 60 & 1.30 & 1.71 & 1.44 & 1.79 & 1.45 & 1.86 & 2.10 & 2.91 & 2.44 & 2.76 & 2.41 & 3.53 \\
\hline 70 & 1.31 & 1.74 & 1.45 & 1.80 & 1.47 & 1.88 & 2.12 & 2.88 & 2.43 & 3.55 & 2.39 & 3.54 \\
\hline 80 & 1.29 & 1.79 & 1.43 & 1.83 & 1.45 & 1.86 & 2.09 & 2.85 & 2.45 & 3.52 & 2.37 & 3.42 \\
\hline 90 & 1.25 & 1.76 & 1.44 & 1.82 & 1.44 & 1.83 & 2.03 & 2.77 & 2.45 & 3.44 & 2.41 & 3.39 \\
\hline
\end{tabular}

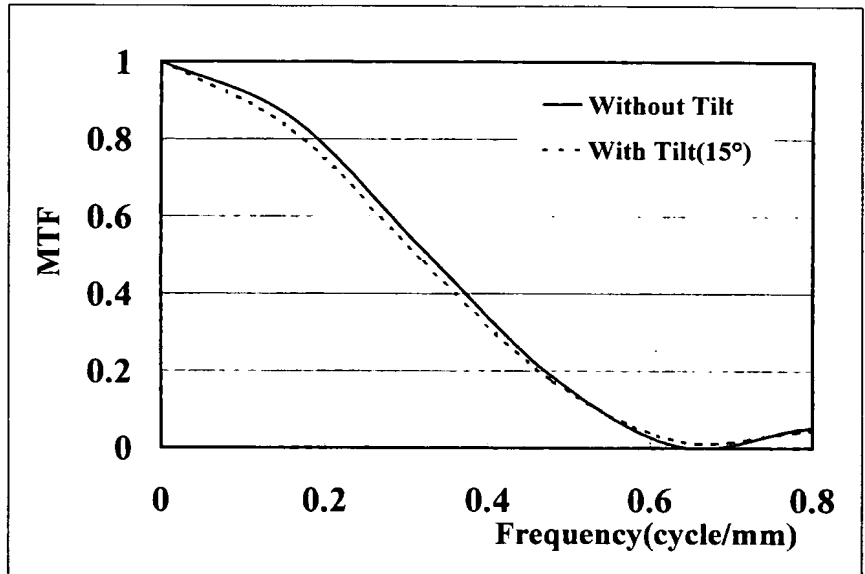

Fig. 10 Relation of MTF to the X-axis.

\section{3-4 空間分解能}

Fig. 10にaxial面内のX軸方向のMTFを示す.ガント リ傾斜させることにより，X軸方向のMTFの劣化が確 認された。Y軸方向に関しても同様の結果が得られ た。

\section{4. 考 察}

スパイラルピッチを変化させてもSSPzおよびMPR 画像のSSPの半值幅に変化がないことから，AAIを用 いることで，ガントリ傾斜させた場合でも，スパイラ ルピッチに関係なく実効スライス厚が一定であること が確認された。また，サンプリング密度の違いによる 補正誤差の関与の仕方は違うと考えられるが，再構成 画像に与える影響は同等と考えられた。これは，患者 の状態，スキャン範囲などに合わせてスパイラルピッ チを柔軟に設定できることを示している。

次に，ガントリ傾斜によるMPR画像への影響に関 しては，X軸，Y軸，Z軸ともに空間分解能の劣化が認

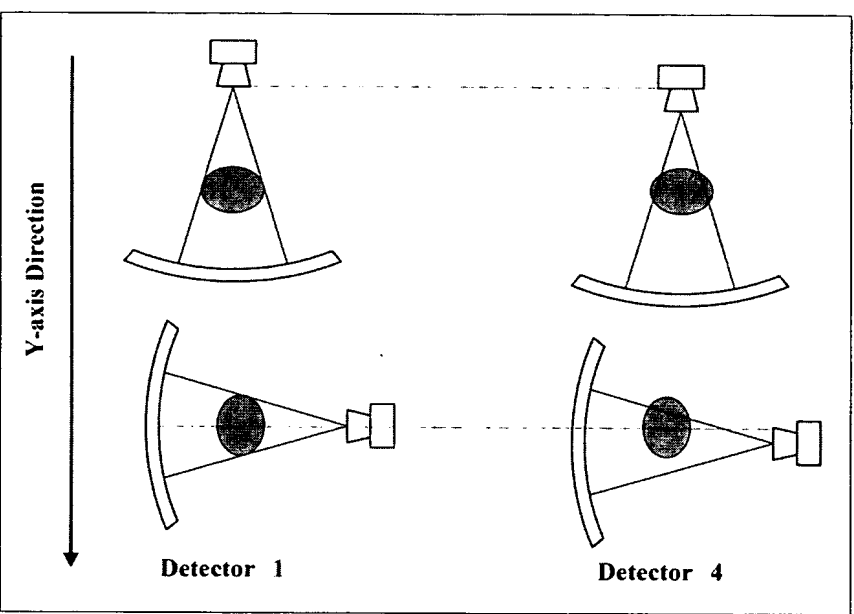

Fig. 11 Difference in actual data with gantry tilt.

められた．その原因としてガントリ傾斜補正誤差が考 えられるが，ガントリ傾斜補正はY 軸，Z軸方向にし か行って捛らず，X軸方向に関しては補正誤差は起こ らない。また，SDCTにおけるspiral scanではガントリ 傾斜させてもX軸方向の分解能は変化しないと報告さ れている1，2). しかし今回，axial画像の面内分解能に 颃いて，X軸方向に関してもMTFの劣化が認められて いる.ここでSDCTとMDCTとの違いを考えると， Z 軸方向の検出器の数である.ガントリ傾斜がない場 合，スキャン位置と管球位置が同じであれば各検出器 における実デー夕は同一である。しかし，ガントリ傾 斜させることにより検出器各列のスキャン中心がずれ るために検出器ごとの実データが異なることになる (例えば，スライスコリメーション $4 \times 1.0 \mathrm{~mm}$ ガントリ 傾斜 $25^{\circ}$ の場合, 検出器 1 と検出器 4 ではスキャン中 心が約 $1.4 \mathrm{~mm}$ 変位することになる)(Fig. 11)。このた め再構成された画像の面内空間分解能に劣化が生じた ものと考える．これは，X，Y，Z軸すべての方向で起 
こると考えられ，Y，Z軸にも同様に空間分解能の少 化が認められると考えられる。本研究においても，ガ ントリ傾斜することによりすべての方向ともに，同等 の空間分解能の劣化が認められ，上記原因に起因する と考えられた。ガントリ傾斜補正がない場合Y，Z軸 方向の空間分解能の劣化はX軸方向より大きいと考え られ，ガントリ傾斜補正の有用性が示唆された。

\section{5. 結 語}

今回のSSP測定はMPR画像のプロファイルカーブを 用いて行ったため, MPR画像作成時の誤差やプロフ アイルカーブをとるときの測定䛠差が含まれるが, ガ
ントリ傾斜補正することで若干の空間分解能の低下が 起こることが確認できた。 また，これまではガントリ 傾斜スキャン補正がなかったため, ポジショニングを 工夫することで義歯, 体内金属などのアーチファクト を避けていた，そのため患者への負担が大きくなり， 体動を誘発する原因にもなっていた。しかし，ガント リ傾斜補正が可能になったことにより，患者への負担 なしでアーチファクトを軽減することができるように なり，非常に有用であると考える。

なお,この研究の要旨は第29回日本放射線技術学会 秋季学術大会(名古屋)にて発表した。

\section{参考文献}

1) 河野博文, 鈴木 徽, 松浦 茂, 他：ヘリカルCTにおける ガントリ傾斜の影響 垂直方向に生じる不鋭. 日放技誌, 48(4)，608-613，(2001).

2) 河野博文, 鈴木 徹, 松浦 茂, 他：ヘリカルCTにおける ガントリ傾斜の影響 一次元フィルタの有用性. 日放技 誌, 48(5)，687-692，(2001).

3) 白石順二, 花岡信子, 宇都宮あかね，他：CT検査における ガントリ傾斜觕度の影算. 日放技学誌, 53(1)，19-24， (i 997$)$.

4)藤井健二, 计汕勝美, 井田蒌宏, 他：X線CT装置のMPR表 示における表示角度と空間分解能の関係. 日本放射線技術 学会第56回総合学術大会, 横浜, 一般研究発表後抄録, 70, (2000).

5) 计阙勝美, 井田淁去, 鈴木厚次, 他：ヘリカルCTにおける 简易SSP測定法. 日本放射線技術学会第56回総合学術大
会, 横浜, 一般研究発表後抄録, 73, (2000).

6) 村田勝俊：シーメンスのマルチスライスCT-SOMATOM Volume Zoom一。 日放技学誌, 56(12)，1406-1410, (2000).

7)原 孝則, 加藤秀紀, 秋山充年, 他: multi-slice CT (MSCT)における面内空間分解能の基礎的検討. 日放技学 誌, 58(4)，473-478，(2002).

8)勝田昭一, 花井耕造, 国井岳夫, 他: ヘリカルCTにおける スライス感度プロフィ・ルの撮像领域内位置依存性. 口放 技学誌, 55(11)，1109-1114，(1999).

9) 辻岡勝美, 井田蒌去, 高橋康方, 他 : マルチスライスCTの 基礎的検討(第 6 報)FOV上の任意点におけるSlice Sensitive Profile. 日本放射線技術学会第56回総合学術大会, 横浜, 一般研究発表後抄録，68，(2000). 
Fig. 1 ガントリ傾斜が検出器に及はす影響

(a)ガントリ傾斜なし

(b)ガントリ傾斜あり

Fig. 2 ガントリ傾斜補正
(a) Y軸方向
(b) Z軸方向

Fig. 3 ガントリ傾斜補正

(a)正確なガントリ傾斜補正

(b) ガントリ傾斜補正誤差 (オーバラップ)

(c) ガントリ傾斜補正誤差 (ギャップ)

Fig. 4 X-Y平面のSSPを測定するときに使用するMPR画像 coronalからsagittalへ10 ごとに作成し，それぞれの画像のhorizontal方向のprofileよりSSPを求める。

Fig. 5 微小球体配置位置

Fig. 6 ガントリ傾斜をつけたときのSSPz

Fig. 7 Y-Z平面におけるスパイラルピッチとFWHMの関係(スキャン中心)

$0 ： \mathrm{Y}$ 軸方向のSSPの半值幅 $90: \mathrm{Z}$ 軸方向のSSPの半值幅

Fig. 8 Y-Z平面におけるガントリ傾斜とFWHMの関係

$0 ： \mathrm{Y}$ 軸方向のSSPの半值幅 90 : Z軸方向のSSPの半值幅

Fig. 9 Y-Z平面における被写体位置とFWHMの関係( $\mathrm{Y}$ 軸方向に $15 \mathrm{~cm}$ 変位)

0 : Y 軸方向のSSPの半值幅 $90: Z$ 軸方向のSSPの半值幅

Fig. 10 axial面内のX軸方向のMTF

Fig. 11 ガントリ傾斜により各検出器のスキャン中心からずれたために起こる実データの相違

Table X-Y平面における被写体位置とFWHM，FWTMとの関係

$0: X$ 軸方向のSSPの半值幅, $1 / 10$ 幅 90 : Y 軸方向のSSPの半值幅, $1 / 10$ 幅 